\title{
Synthesis, Characterization, and Antimicrobial Activities of Coordination Compounds of Aspartic Acid
}

\author{
T. O. Aiyelabola, ${ }^{1,2}$ D. A. Isabirye, ${ }^{2}$ E. O. Akinkunmi, ${ }^{3}$ O. A. Ogunkunle, ${ }^{1}$ and I. A. O. Ojo ${ }^{1}$ \\ ${ }^{1}$ Department of Chemistry, Obafemi Awolowo University, Ife Central, Ile-Ife 220282, Osun State, Nigeria \\ ${ }^{2}$ Department of Chemistry NWU, Mafikeng Campus, Private Bag X2046, Mmabatho 2735, South Africa \\ ${ }^{3}$ Department of Pharmaceutics, Obafemi Awolowo University, Ife Central, Ile-Ife 220282, Osun State, Nigeria
}

Correspondence should be addressed to T. O. Aiyelabola; ttlhaye@yahoo.com

Received 1 September 2015; Accepted 27 October 2015

Academic Editor: Nigam P. Rath

Copyright (C) 2016 T. O. Aiyelabola et al. This is an open access article distributed under the Creative Commons Attribution License, which permits unrestricted use, distribution, and reproduction in any medium, provided the original work is properly cited.

\begin{abstract}
Coordination compounds of aspartic acid were synthesized in basic and acidic media, with metal ligand M : L stoichiometric ratio $1: 2$. The complexes were characterized using infrared, electronic and magnetic susceptibility measurements, and mass spectrometry. Antimicrobial activity of the compounds was determined against three Gram-positive and three Gram-negative bacteria and one fungus. The results obtained indicated that the availability of donor atoms used for coordination was a function of the $\mathrm{pH}$ of the solution in which the reaction was carried out. This resulted in varying geometrical structures for the complexes. The compounds exhibited a broad spectrum of activity and in some cases better activity than the standard.
\end{abstract}

\section{Introduction}

Much attention is being paid to coordination compounds as potential antimicrobial agents in recent times. This is due to the improved activity of drugs administered as complexes [1-6]. It has been suggested that ligands with nitrogen and oxygen donor systems might inhibit enzyme production. This is because the enzymes which require these groups for their activity appear to be especially more susceptible to deactivation by the metal ion upon chelation [2]. Such compounds include coordination compounds of amino acids, such as aspartic acid. Aspartic acid (Figure 1) is a naturally occurring amino acid and a component of the active centre of some enzymes. It possesses three potential donor sites (one amine group and two carboxyl ones) [7, 8]. Aspartic acid has been reported as bidentate, as tridentate, and as a bridging ligand [9-15]. Its coordination behaviour may therefore be studied by comparing the complexes it forms with a series of metal ions of the same valency at relevant $\mathrm{pH}$ ranges $[12,14,15]$. Various structural possibilities for the corresponding metal complexes are thus expected [16-20]. Coordination compounds of amino acids, such as histidine [21], arginine, glutamic acid $[14,16]$, and aspartic acid $[13,22]$, have been studied.
These coordination compounds were reported to demonstrate activity varying from marginal to significantly good antimicrobial properties. However, little attention has been focused on coordination compounds of aspartic acid as a tridentate ligand. As a result of resistance to the drugs currently in use and the emergence of new diseases, there is a continuous need for the synthesis and identification of new compounds as potential antimicrobial agents. Therefore we considered it necessary to study the effects of the possible varying structures of coordination compounds of aspartic acid on their antimicrobial activity, as this would yield information useful for designing antimicrobial agents. We therefore report the syntheses of coordination compounds of aspartic acid in acidic and basic media and their characterization and antimicrobial activities.

\section{Experimental}

2.1. Materials and Methods. All reagents and solvents used were of analytical grade. The infrared spectra were recorded on a Genesis II FTIR spectrophotometer in the range $450-4200 \mathrm{~cm}^{-1}$. The electronic absorption spectra of 
<smiles>[NH3+]C(CC(=O)O)C(=O)[O-]</smiles>

FIgURE 1

the complexes in the range $200-1000 \mathrm{~nm}$ were obtained with a Genesis $10 \mathrm{UV}-\mathrm{Vis}$ spectrophotometer, solid reflectance. Melting points or decomposition temperatures (m.p./d.t.) were measured using open capillary tubes on a Gallenkamp (variable heater) melting point apparatus. The in vitro antimicrobial properties of the complexes were determined using a modification of the literature procedure [23]. Magnetic susceptibility was obtained using a Gouy balance at room temperature. Mass spectrometry for one of the complexes was carried out using Fisons VG Quattro spectrophotometer.

2.2. Syntheses of Complexes. The complexes were prepared according to a modification of literature procedure $[13,24$, 25]. The general equations for the reactions are as follows:

$\mathrm{ML}_{2}$ complexes:

$\mathrm{MCl}_{2}+2 \mathrm{H}_{2} \mathrm{~L} \rightarrow \mathrm{MHL}_{2}+2 \mathrm{HCl}$

$\mathrm{Na}_{2}\left[\mathrm{ML}_{2}\right]$ complexes:

$\mathrm{MCl}_{2}+2 \mathrm{H}_{2} \mathrm{~L}+2 \mathrm{NaOH} \rightarrow \mathrm{Na}_{2}\left[\mathrm{ML}_{2}\right]+2 \mathrm{HCl}+2 \mathrm{H}_{2} \mathrm{O}$

where $\mathrm{M}=\mathrm{Co}(\mathrm{II}), \mathrm{Cu}(\mathrm{II}), \mathrm{Mn}(\mathrm{II}), \mathrm{Ni}(\mathrm{II}), \mathrm{Cd}(\mathrm{II}) ; \mathrm{L}=$ $(+)$-aspartic acid.

2.2.1. $\mathrm{ML}_{2}$ Complexes. A solution of (+)-aspartic acid $(0.02 \mathrm{M}, 2.67 \mathrm{~g})$ was added to $0.01 \mathrm{M}$ of appropriate metal(II) chloride salt $(1.62,2.17,2.43,2.51$, and $2.69 \mathrm{~g})$ for copper, cadmium, nickel, cobalt, and manganese, respectively, and dissolved in $20 \mathrm{~mL}$ of distilled water, with stirring; $\mathrm{pH}$ range for the reactions was 2.01-2.21. The mixtures were heated with stirring for $2 \mathrm{~h}$, using a water bath. The resultant solutions were further concentrated until a scum was formed and then cooled. Crystals obtained were filtered and washed with methanol and then dried in a vacuum oven at $60^{\circ} \mathrm{C}$.

2.2.2. $\mathrm{Na}_{2}\left[\mathrm{ML}_{2}\right]$ Complexes. Appropriate metal(II) chloride salt solutions (0.02 M; 3.31, 4.47, 4.88, 5.05, and 5.34 g) for copper, cadmium, nickel, cobalt, and manganese, respectively, were dissolved in minimal amount of distilled water with warming until a clear solution was obtained. (+)Aspartic acid (0.04 M, 5.42 g) was dissolved in distilled water and warmed over a steam bath. $0.04 \mathrm{M} \mathrm{NaOH}$ was then added with stirring, such that the $\mathrm{pH}$ range of the reaction was about $8-10$. The metal(II) solution was then added and the mixture was refluxed for $2 \mathrm{~h}$. The product obtained was allowed to cool overnight with the formation of crystals. The crystals obtained were filtered, washed with methanol, and dried in an oven at $60^{\circ} \mathrm{C}$.

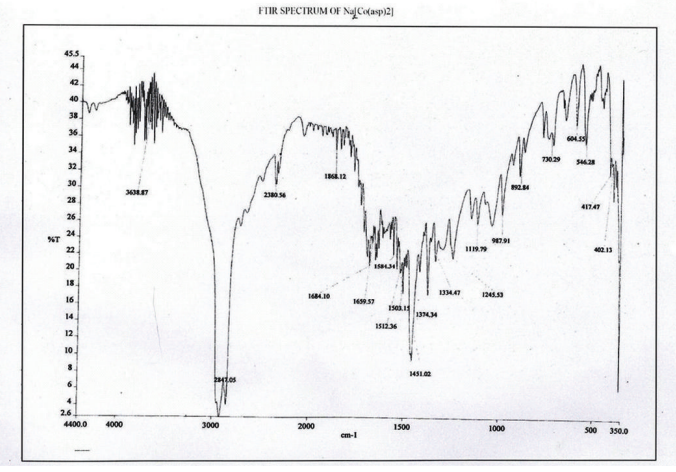

Figure 2: Infrared spectrum for $\mathrm{Na}_{2}\left[\mathrm{Co}(\mathrm{asp})_{2}\right]$.

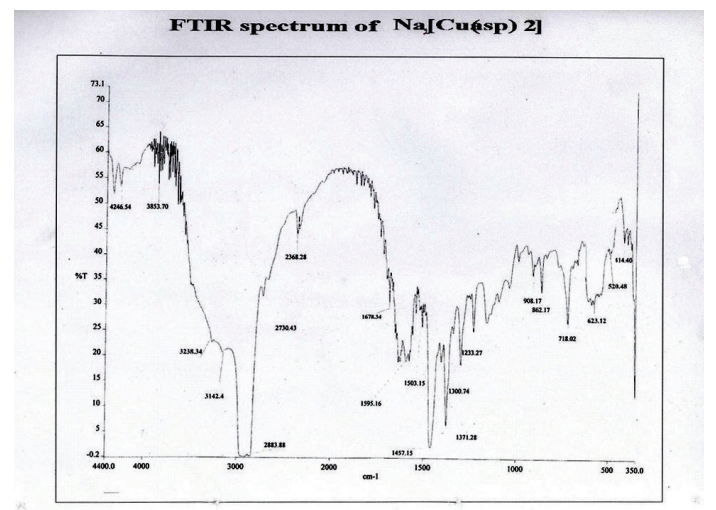

FIgURE 3: Infrared spectrum for $\mathrm{Na}_{2}\left[\mathrm{Cu}(\mathrm{asp})_{2}\right]$.

2.3. Antimicrobial Activity Using Disc Diffusion Assay. The in vitro antimicrobial screening effects of the ligand and complexes were evaluated using the disc diffusion method as previously reported [26]. The strains used were Escherichia coli NCTC 8196, Pseudomonas aeruginosa ATCC 19429, Staphylococcus aureus NCTC 6571, Proteus vulgaris NCIB, Bacillus subtilis NCIB 3610, and one Methicillin resistant S. aureus clinical isolate for bacteria and C. albicans NCYC 6 for fungi. All the tests were performed in triplicate.

\section{Results and Discussion}

3.1. Physicochemical Analysis. All the complexes were insoluble in major organic solvents; however they were soluble in hot water. The melting points or decomposition temperatures for the complexes are shown in Table 1. Most of the complexes decomposed before melting.

3.2. Infrared Spectra. The infrared spectrum of the free ligand exhibited a broad band at $3380 \mathrm{~cm}^{-1}$ which was assigned to the $\mathrm{NH}_{2}$ stretching frequency. Intense bands at 1650 and $1583 \mathrm{~cm}^{-1}$ were observed and are attributed to $\mathrm{COO}^{-}$asy and $\mathrm{COO}^{-}$sy stretching frequencies, respectively [27, 28]. The $\mathrm{COO}^{-}$asymmetric and symmetric stretching frequencies on coordination were shifted to higher and lower wave numbers, for $\mathrm{Na}_{2}\left[\mathrm{ML}_{2}\right]$ complexes, indicating that the oxygen atom of the carboxylate group of the ligand was used for coordination, Figures 2 and $3[12,28]$. For the $\mathrm{ML}_{2}$ complexes the $\mathrm{COO}^{-}$ 
TABLE 1: Some physicochemical properties of the compounds.

\begin{tabular}{|c|c|c|c|c|}
\hline Compound & Empirical formulae & Colour & m.p./d.t. $\left({ }^{\circ} \mathrm{C}\right)$ & Yield (\%) \\
\hline $\mathrm{Co}(d \text {-asp })_{2}$ & $\mathrm{Co}\left(\mathrm{C}_{4} \mathrm{H}_{8} \mathrm{O}_{4} \mathrm{~N}\right)$ & Lilac & 217 & 74.20 \\
\hline $\mathrm{Cu}(d \text {-asp })_{2}$ & $\mathrm{Cu}\left(\mathrm{C}_{4} \mathrm{H}_{8} \mathrm{O}_{4} \mathrm{~N}\right)$ & Blue & 205 & 57.21 \\
\hline $\operatorname{Mn}(d \text {-asp })_{2}$ & $\mathrm{Mn}\left(\mathrm{C}_{4} \mathrm{H}_{8} \mathrm{O}_{4} \mathrm{~N}\right)$ & White & $304(d)$ & 81.84 \\
\hline $\mathrm{Ni}(d \text {-asp })_{2}$ & $\mathrm{Ni}\left(\mathrm{C}_{4} \mathrm{H}_{8} \mathrm{O}_{4} \mathrm{~N}\right)$ & Green & $197(d)$ & 66.00 \\
\hline $\mathrm{Cd}(d \text {-asp })_{2}$ & $\mathrm{Cd}\left(\mathrm{C}_{4} \mathrm{H}_{8} \mathrm{O}_{4} \mathrm{~N}\right)$ & White & $204(d)$ & 62.40 \\
\hline $\mathrm{Na}_{2}\left[\mathrm{Co}(d \text {-asp })_{2}\right]$ & $\mathrm{Na}\left[\mathrm{Co}\left(\mathrm{C}_{4} \mathrm{H}_{8} \mathrm{O}_{4} \mathrm{~N}\right)\right]$ & Purple & $>320$ & 62.60 \\
\hline $\mathrm{Na}_{2}\left[\mathrm{Cu}(d \text {-asp })_{2}\right]$ & $\mathrm{Na}\left[\mathrm{Cu}\left(\mathrm{C}_{4} \mathrm{H}_{8} \mathrm{O}_{4} \mathrm{~N}\right)\right]$ & Blue & $215(d)$ & 84.20 \\
\hline $\mathrm{Na}_{2}\left[\mathrm{Mn}(d \text {-asp })_{2}\right]$ & $\mathrm{Na}\left[\mathrm{Mn}\left(\mathrm{C}_{4} \mathrm{H}_{8} \mathrm{O}_{4} \mathrm{~N}\right)\right]$ & White & $301-303(d)$ & 68.50 \\
\hline $\mathrm{Na}_{2}\left[\mathrm{Ni}(d \text {-asp })_{2}\right]$ & $\mathrm{Na}\left[\mathrm{Ni}\left(\mathrm{C}_{4} \mathrm{H}_{8} \mathrm{O}_{4} \mathrm{~N}\right)\right]$ & Green & $294(d)$ & 62.70 \\
\hline $\mathrm{Na}_{2}\left[\mathrm{Cd}(d \text {-asp })_{2}\right]$ & $\mathrm{Na}\left[\mathrm{Cd}\left(\mathrm{C}_{4} \mathrm{H}_{8} \mathrm{O}_{4} \mathrm{~N}\right)\right]$ & White & $287(d)$ & 69.60 \\
\hline
\end{tabular}

(d): decomposition temperature.

TABLE 2: Electronic spectra bands, for the compounds.

\begin{tabular}{lccccc}
\hline Compound & Band I & Band II & Band III & $d$-d & Magnetic moment (BM) \\
\hline Aspartic acid & 196 & 212 & 8231 & & - \\
$\mathrm{Cu}(\text { asp })_{2}$ & 241 & 259 & 391 & 628,667 & - \\
$\mathrm{Cd}(\text { asp })_{2}$ & 238 & 259 & 271 & 517 & 0.00 \\
$\mathrm{Ni}(\text { asp })_{2}$ & 232 & 265 & - & 4.49 & 5.28 \\
$\mathrm{Co}(\text { asp })_{2}$ & - & 259 & - & 544,568 shld, 682,829 & 5.82 \\
$\mathrm{Mn}(\text { asp })_{2}$ & 226 & 277 & 259 & 667 & 2.20 \\
$\mathrm{Na}_{2}\left[\mathrm{Cu}(\text { asp })_{2}\right]$ & 226 & 238 & 256 & 833,881 & 0.00 \\
$\mathrm{Na}_{2}\left[\mathrm{Cd}(\text { asp })_{2}\right]$ & 226 & 235 & 259 & 637,652 & 1.15 \\
$\mathrm{Na}_{2}\left[\mathrm{Ni}(\text { asp })_{2}\right]$ & - & 241 & 256 & $526,541,565$ & 4.33 \\
$\mathrm{Na}_{2}\left[\mathrm{Co}(\text { asp })_{2}\right]$ & 223 & 235 & 265 & $526,541,673$ & \\
$\mathrm{Na}_{2}\left[\mathrm{Mn}(\text { asp })_{2}\right]$ & 223 & & &
\end{tabular}

asymmetric stretching frequencies were shifted to higher frequencies compared with that of the ligand in the order Co $>\mathrm{Mn}>\mathrm{Ni}$ with the exception of the copper complex in which an hypsochromic shift was observed. No shift was observed for the cadmium complex. It is suggested that this arrangement may be as a result of the size of the metal ions [28-30]. In some of the $\mathrm{Na}_{2}\left[\mathrm{ML}_{2}\right]$ complexes (Table 2) two bands were observed on coordination for the $\mathrm{COO}^{-}$asymmetric and symmetric stretching frequencies. These indicate the possible mode of coordination of aspartic acid to the central metal ion via both oxygen atoms of the $\alpha$ - and $\beta$-carboxylate ion. Consequently, in these complexes, aspartic acid may be said to be tridentate, an observation that is in agreement with that obtained by previous workers [10]. Hypsochromic shifts were observed for the $-\mathrm{NH}_{2}$ frequencies on coordination, for the $\mathrm{ML}_{2}$ and $\mathrm{Na}_{2}\left[\mathrm{ML}_{2}\right]$ complexes. This indicates bond elongation on coordination. It therefore suggests probable square planar and distorted octahedral geometry for the complexes, respectively. New bands in the spectra of the complexes at $500-598 \mathrm{~cm}^{-1}$ were assigned to $(\mathrm{M}-\mathrm{N})$ stretching frequency. The participation of the lone pairs of electrons on the $\mathrm{N}$ of the amino group in the ligand in coordination is supported by these band frequencies [31]. Bands in the region of 604$724 \mathrm{~cm}^{-1}$ indicate the formation of $\mathrm{M}-\mathrm{O}$ bond and further support the coordination of the ligand to the central metal ions via the oxygen atom of the carboxylate group [29].
3.3. Electronic Spectra and Magnetic Moment. The electronic spectra of the ligands showed three absorption bands at 196, 212 , and $232 \mathrm{~nm}$ assigned as the $n \rightarrow \sigma^{*}, n \rightarrow \pi^{*}$, and $\pi^{*} \rightarrow \pi^{*}$ transitions of the major chromophores, $\mathrm{NH}_{2}$ and $\mathrm{COO}^{-}$, present in the ligand molecules. On coordination, however, shifts were observed in these bands in addition to $d$ - $d$ transitions bands (Table 3 ). These in conjunction with the magnetic moment of the complexes were used to propose probable geometry of the complexes obtained.

3.3.1. $\mathrm{Na}_{2}\left[\mathrm{ML}_{2}\right]$ Complexes. The spectrum for the copper(II) complex displayed a well resolved band at $667 \mathrm{~nm}$, Figure 4 , assigned as ${ }^{2} \mathrm{~B}_{1 \mathrm{~g}} \rightarrow{ }^{2} \mathrm{E}_{\mathrm{g}}$ transition, which suggests an octahedral geometry [32]. This proposed geometry was corroborated by its magnetic moment of $2.47 \mathrm{BM}$, indicative of a tetragonally distorted octahedral geometry [33]. A weak band at $833 \mathrm{~nm}$ assigned as charge transfer band was observed in the spectrum for the cadmium(II) complex. This was supported by its magnetic moment of zero, indicative of a diamagnetic $\mathrm{Cd}(\mathrm{II})$ complex with filled $4 \mathrm{~d}$ orbital [32, 33]. The Ni(II) complex exhibited a shoulder at $637 \mathrm{~nm}$ and a strong band at $652 \mathrm{~nm}$, which were assigned to ${ }^{3} \mathrm{~A}_{2 \mathrm{~g}}(\mathrm{~F}) \rightarrow$ ${ }^{5} \mathrm{~T}_{1 \mathrm{~g}}$ and ${ }^{3} \mathrm{~A}_{2 \mathrm{~g}}(\mathrm{~F}) \rightarrow{ }^{1} \mathrm{E}_{\mathrm{g}}$ transitions. The magnetic moment of 3.28 BM however is suggestive of an octahedral geometry $[34,35]$. The cobalt(II) complex gave a shoulder at $526 \mathrm{~nm}$, 
TABLE 3: Relevant IR bands for the compounds.

\begin{tabular}{|c|c|c|c|c|c|}
\hline Band & $\bar{v}_{\mathrm{s}}\left(\mathrm{NH}_{2}\right)$ & $\bar{\nu}_{\text {asy }}\left(\mathrm{COO}^{-}\right)$ & $\bar{v}_{\mathrm{sy}}\left(\mathrm{COO}^{-}\right)\left(\mathrm{cm}^{-1}\right)$ & $\bar{\nu}(\mathrm{M}-\mathrm{N})$ & $\bar{\nu}(\mathrm{M}-\mathrm{O})$ \\
\hline Aspartic acid & $3380 w$ & $1650 \mathrm{~s}$ & $1583 \mathrm{~s}$ & - & - \\
\hline $\mathrm{Cu}(\mathrm{asp})_{2}$ & $3433 \mathrm{~m}$ & $1641 w$ & $1509 w$ & $552 \mathrm{~s}$ & $656 \mathrm{~m}$ \\
\hline $\mathrm{Cd}(\mathrm{asp})_{2}$ & $3333 w$ & $1650 \mathrm{~s}$ & $1539 s$ & $549 \mathrm{~s}$ & $724 \mathrm{~s}$ \\
\hline $\mathrm{Ni}(\text { asp })_{2}$ & $3357 w$ & $1674 \mathrm{~s}$ & $1559 \mathrm{~s}$ & $548 w$ & $721 w$ \\
\hline $\mathrm{Co}(\mathrm{asp})_{2}$ & $3143 \mathrm{br}$ & $1684 \mathrm{~s}$ & $1561 \mathrm{~s}$ & $566 \mathrm{w}$ & $665 \mathrm{~m}$ \\
\hline $\mathrm{Mn}(\mathrm{asp})_{2}$ & $3309 w$ & $1678 \mathrm{~m}$ & $1547 w$ & $550 \mathrm{~s}$ & $598 \mathrm{~m}$ \\
\hline $\mathrm{Na}_{2}\left[\mathrm{Cu}(\mathrm{asp})_{2}\right]$ & $3238,3142 \mathrm{br}$ & $1678 \mathrm{~s}, 1595 \mathrm{~m}$ & $1503 \mathrm{~s}, 1371 \mathrm{~s}$ & $520 \mathrm{~m}$ & $623 \mathrm{br}$ \\
\hline $\mathrm{Na}_{2}\left[\mathrm{Cd}(\mathrm{asp})_{2}\right]$ & $3025 b r$ & $1687 \mathrm{~s}$ & $1532 \mathrm{br}$ & $598 \mathrm{~s}$ & $619 \mathrm{~s}$ \\
\hline $\mathrm{Na}_{2}\left[\mathrm{Ni}(\mathrm{asp})_{2}\right]$ & $3190 w, b r$ & $1667 \mathrm{sh}$ & $1547 \mathrm{~s}$ & $500 \mathrm{~m}$ & $672 \mathrm{~s}$ \\
\hline $\mathrm{Na}_{2}\left[\mathrm{Co}(\mathrm{asp})_{2}\right]$ & - & $1684 \mathrm{~s}, 1584 \mathrm{w}$ & $1512 \mathrm{~s}, 1375 \mathrm{~s}$ & $546 \mathrm{~s}$ & $604 \mathrm{~s}$ \\
\hline $\mathrm{Na}_{2}\left[\mathrm{Mn}(\mathrm{asp})_{2}\right]$ & $3357 \mathrm{br}$ & $1686 \mathrm{~s}$ & $1542 \mathrm{~m}$ & $550 \mathrm{~s}$ & $658 \mathrm{~s}$ \\
\hline
\end{tabular}

asp: aspartic acid; w: weak; m: medium; s: strong.

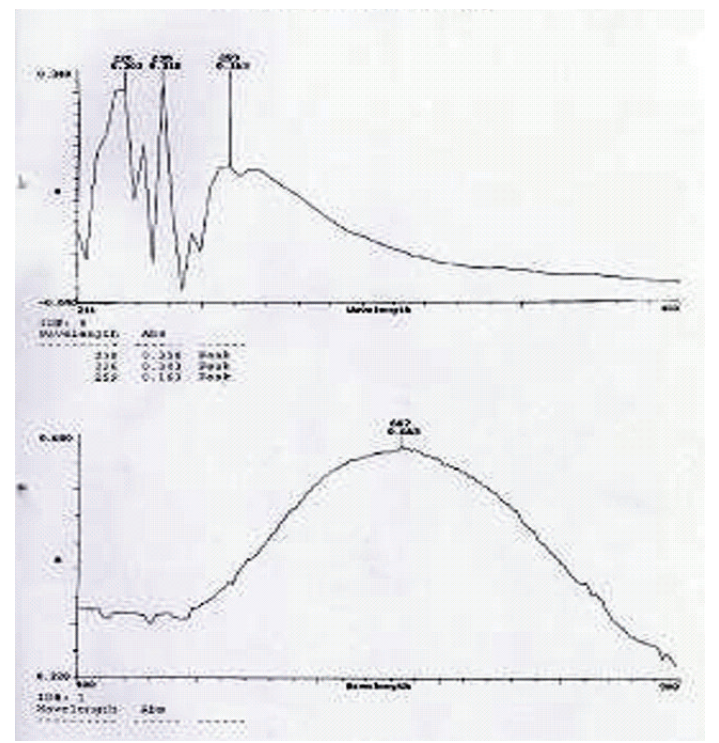

Figure 4: UV-Vis spectrum for $\mathrm{Na}_{2}\left[\mathrm{Cu}(\text { asp })_{2}\right]$.

a strong band at $541 \mathrm{~nm}$, and a weak band at $565 \mathrm{~nm}$ typical of a six coordinate, octahedral geometry for cobalt(II) and were attributed to ${ }^{4} \mathrm{~T}_{1 \mathrm{~g}}(\mathrm{~F}) \rightarrow{ }^{4} \mathrm{~A}_{2 \mathrm{~g}}(\mathrm{~F}),{ }^{4} \mathrm{~T}_{1 \mathrm{~g}}(\mathrm{~F}) \rightarrow{ }^{4} \mathrm{~T}_{2 \mathrm{~g}}(\mathrm{~F})$, and ${ }^{4} \mathrm{~T}_{1 \mathrm{~g}}(\mathrm{~F}) \rightarrow{ }^{4} \mathrm{~T}_{1 \mathrm{~g}}(\mathrm{~F})$ transitions. This geometry was corroborated by a magnetic moment of $5.40 \mathrm{BM}$ [34-36]. The $\mathrm{Mn}$ (II) complex exhibited weak absorption bands at 526, 541, and $673 \mathrm{~nm}$ which are consistent with a six-coordinate, octahedral geometry and were assigned to ${ }^{6} \mathrm{~A}_{1 \mathrm{~g}} \rightarrow{ }^{4} \mathrm{~T}_{2 \mathrm{~g}}(\mathrm{G})$, ${ }^{6} \mathrm{~A}_{1 \mathrm{~g}} \rightarrow{ }^{4} \mathrm{~T}_{1 \mathrm{~g}}(\mathrm{G})$, and ${ }^{6} \mathrm{~A}_{1 \mathrm{~g}} \rightarrow{ }^{4} \mathrm{E}_{\mathrm{g}}(\mathrm{G})$ transitions; its magnetic moment of 5.82 BM complements this [2].

3.3.2. $M L_{2}$ Complexes. The spectrum for the copper(II) complex displayed two bands at 628 and $667 \mathrm{~nm}$, Figure 5, assigned to ${ }^{2} \mathrm{~B}_{1 \mathrm{~g}} \rightarrow{ }^{2} \mathrm{E}_{\mathrm{g}}$ and ${ }^{2} \mathrm{E}_{\mathrm{g}} \rightarrow{ }^{2} \mathrm{~A}_{1 \mathrm{~g}}$ transitions. The complex exhibited a magnetic moment of 2.2 BM indicative of a mononuclear copper(II) complex with 4-coordinate

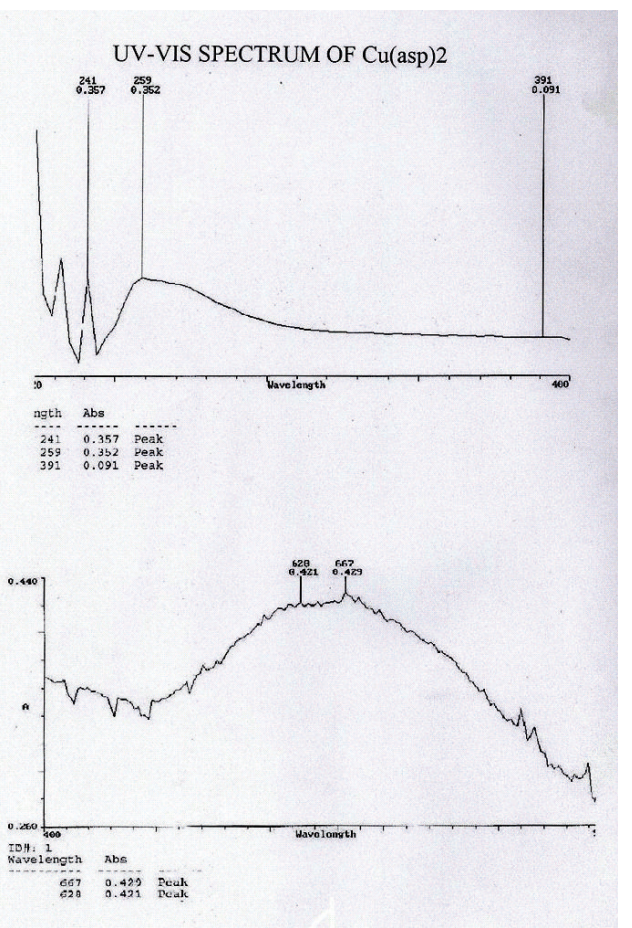

Figure 5: UV-Vis spectrum for $\mathrm{Cu}(\operatorname{asp})_{2}$.

square planar geometry [37-39]. The cadmium complex exhibited no $d$ - $d$ transition band. A magnetic moment of zero corroborates this; however based on valence bond theory a tetrahedral geometry is proposed, and this is in agreement with previous reports $[32,39]$. The nickel complex exhibited a well-defined band at $517 \mathrm{~nm}$ assigned as ${ }^{3} \mathrm{~A}_{2 \mathrm{~g}} \rightarrow{ }^{1} \mathrm{E}_{\mathrm{g}}$. A magnetic moment of $1.15 \mathrm{BM}$ was observed for this complex. This is interpreted as a low spin-high spin equilibrium mixture of tetrahedral-square planar complex [40]. The Co(II) complex exhibited two absorption bands at 499 and $520 \mathrm{~nm}$, assigned as ${ }^{4} \mathrm{~A}_{2 \mathrm{~g}} \rightarrow{ }^{4} \mathrm{~T}_{2 \mathrm{~g}}(\mathrm{~F})$ and ${ }^{4} \mathrm{~A}_{2 \mathrm{~g}} \rightarrow{ }^{4} \mathrm{~T}_{1 \mathrm{~g}}(\mathrm{~F})$, respectively, typical for a tetrahedral geometry. This is corroborated by a magnetic 


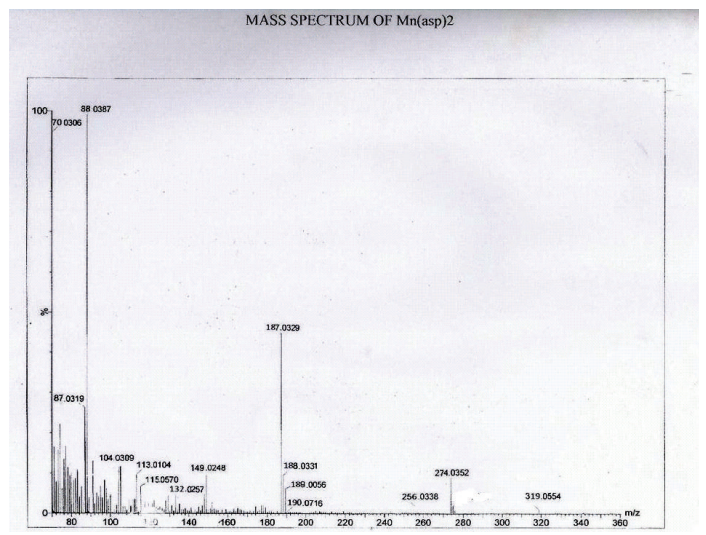

Figure 6: Mass spectrum of $\mathrm{Mn}(\mathrm{asp})_{2}$.

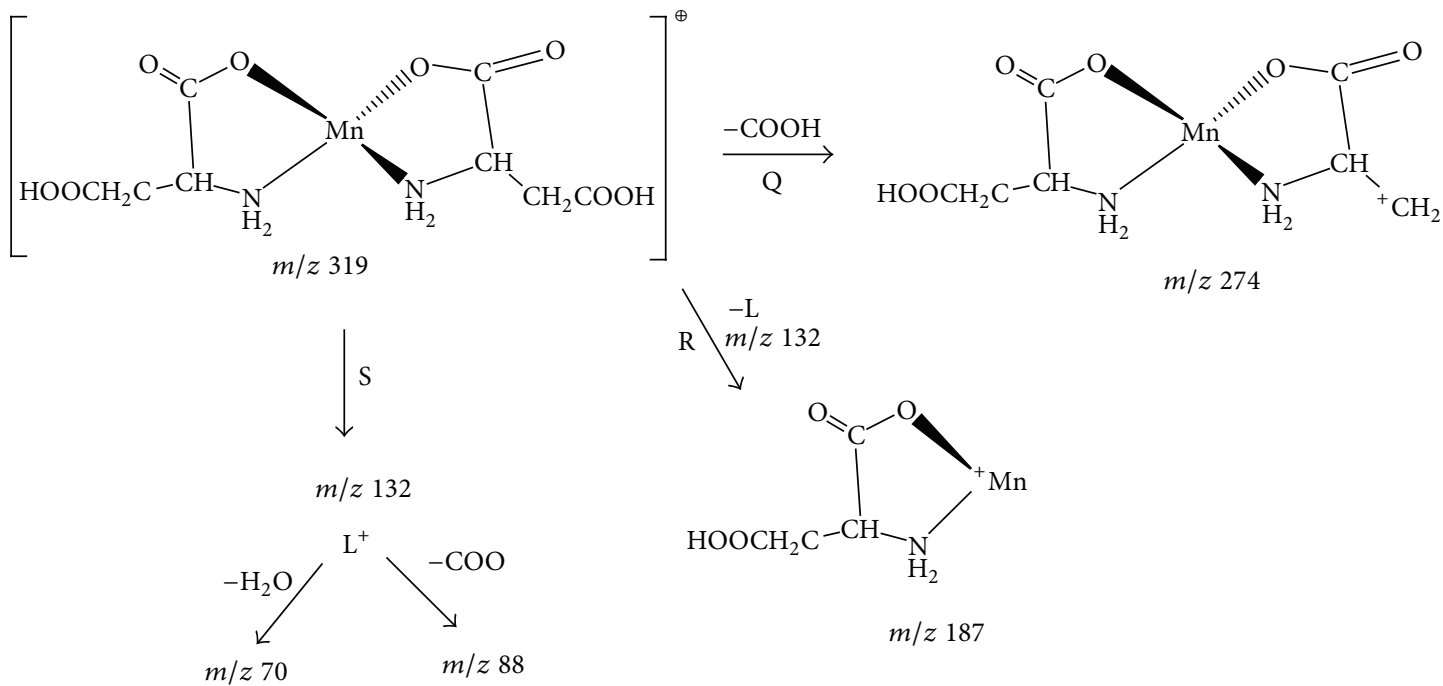

FIGURE 7: Proposed fragmentation pattern of $\mathrm{Mn}(\mathrm{asp})_{2}$.

moment of $4.33 \mathrm{BM}$ [38]. Bands at 544, 568, and 682 for the $\mathrm{Mn}(\mathrm{II})$ complex were assigned to ${ }^{6} \mathrm{~A}_{1 \mathrm{~g}} \rightarrow{ }^{4} \mathrm{~T}_{\mathrm{lg}}{ }^{6} \mathrm{~A}_{1 \mathrm{~g}} \rightarrow{ }^{4} \mathrm{E}_{\mathrm{g}}$, and ${ }^{6} \mathrm{~A}_{1 \mathrm{~g}} \rightarrow{ }^{4} \mathrm{E}_{\mathrm{g}}$ transitions and a charge transfer band at $829 \mathrm{~nm}[41]$.

3.4. Mass Spectrometry. The electronic impact mass spectrum of the complex $\mathrm{Mn}(\mathrm{asp})_{2}$ (Figure 6) was obtained and a probable fragmentation pattern was proposed (Figure 7). The spectrum showed a weak peak at $m / z 319$ (4\%), which coincides with the calculated molecular ion. The fragmentation of the molecular ion was proposed to occur via three pathways, $\mathrm{Q}, \mathrm{R}$, and S. Pathway Q corresponds to the loss of $\beta-\mathrm{COOH}$ to give a peak at $m / z 274$ (9\%). Pathway R corresponds to the extrusion of a ligand as a radical to give a peak at $\mathrm{m} / \mathrm{z} 187$ $(42 \%)$. While for pathway $S$ the molecular ion fragments with the ligand as a positive ion with $m / z 132(4 \%)$. This ion further fragmented with the loss of COO to yield a peak at $m / z 88$, the base peak. It also fragmented giving a peak at $m / z 70$ (92\%) with the loss of a water molecule.
Thus, from the foregoing, it was proposed that the coordination mode of aspartic acid is a function of the $\mathrm{pH}$ at which the reaction was carried out, as this may invariably determine the donor atoms of the ligand available for coordination $[42,43]$. From previous reports, it has been reported that the participation of a particular functional group in metal binding depends partly on its acid dissociation constant [42]. In this case, aspartic acid has $\alpha$-carboxylic acid moiety with $\mathrm{pK}_{\mathrm{a}}$ of 2.09 and a $\beta$-carboxylic acid moiety with $\mathrm{pK}_{\mathrm{a}}$ of 3.86 . This implies that for the donor atoms to be readily available for complex formation the $\mathrm{pH}$ of the reaction must fall within these ranges. This was evident in the complexes formed; this is because at $\mathrm{pH}$ ranges greater than 4.0 , both the oxygen donor atoms from the $\alpha$ - and $\beta$-carboxylic group were available for binding [9-11]. It therefore acts as a tridentate ligand [9$11,42]$.

It is further suggested that energy consideration as a result of the stability of the chelate ring also enhanced the coordination mode of the ligand. This is because although the $\mathrm{NH}_{3}{ }^{+}$ion has a $\mathrm{pK}_{\mathrm{a}}$ value of 9.82 (Figure 8), even at low $\mathrm{pH}$, 
TABLE 4: Antimicrobial activities of the compounds.

\begin{tabular}{|c|c|c|c|c|c|c|c|}
\hline Microorganisms & E. coli & P. aeruginosa & P. vulgaris & S. aureus & B. subtilis & MRSA & C. albicans \\
\hline Aspartic acid & $6.0 \pm 0.2$ & $6.0 \pm 0.7$ & $6.0 \pm 0.0$ & $6.0 \pm 0.1$ & $6.0 \pm 0.1$ & $6.0 \pm 0.5$ & $8.0 \pm 1.0$ \\
\hline $\mathrm{Cu}(\mathrm{asp})_{2}$ & $6.0 \pm 0.0$ & $12.0 \pm 0.3$ & $6.0 \pm 0.2$ & $12.0 \pm 0.7$ & $12.0 \pm 0.0$ & $16.0 \pm 0.5$ & $6.0 \pm 0.3$ \\
\hline $\mathrm{Cd}(\mathrm{asp})_{2}$ & $8.0 \pm 0.2$ & $8.0 \pm 0.0$ & $6.0 \pm 0.6$ & $11.0 \pm 0.1$ & $8.0 \pm 0.3$ & $11.0 \pm 0.0$ & $17.0 \pm 0$ \\
\hline $\mathrm{Ni}(\text { asp })_{2}$ & $6.0 \pm 0.5$ & $6.0 \pm 0.1$ & $6.0 \pm 0.7$ & $6.0 \pm 1.0$ & $6.0 \pm 0.9$ & $6.0 \pm 0.2$ & $6.0 \pm 0.2$ \\
\hline $\mathrm{Co}(\mathrm{asp})_{2}$ & $6.0 \pm 0.6$ & $6.0 \pm 0.1$ & $6.0 \pm 0.1$ & $6.0 \pm 0.0$ & $6.0 \pm 0.0$ & $6.0 \pm 0.8$ & $6.0 \pm 0.6$ \\
\hline $\mathrm{Mn}(\mathrm{asp})_{2}$ & $8.0 \pm 0.5$ & $8.0 \pm 0.8$ & $8.0 \pm 0.3$ & $14.0 \pm 0.2$ & $20.0 \pm 0.5$ & $10.0 \pm 0.3$ & $6.0 \pm 0.4$ \\
\hline $\mathrm{Na}_{2}\left[\mathrm{Cu}(\mathrm{asp})_{2}\right]$ & $9.0 \pm 1.0$ & $6.0 \pm 0.3$ & $10.0 \pm 0.7$ & $36.0 \pm 0.8$ & $16.0 \pm 0.3$ & $23.0 \pm 0.8$ & $16.0 \pm 0.9$ \\
\hline $\mathrm{Na}_{2}\left[\mathrm{Cd}(\operatorname{asp})_{2}\right]$ & $6.0 \pm 0.0$ & $11.0 \pm 0.4$ & $6.0 \pm 1.0$ & $10.0 \pm 0.5$ & $6.0 \pm 0.6$ & $6.0 \pm 0.3$ & $37.0 \pm 0.1$ \\
\hline $\mathrm{Na}_{2}\left[\mathrm{Ni}(\mathrm{asp})_{2}\right]$ & $8.0 \pm 0.7$ & $6.0 \pm 0.8$ & $6.0 \pm 0.4$ & $11.0 \pm 0.9$ & $13.0 \pm 0.4$ & $18.0 \pm 0.3$ & $15.0 \pm 0.9$ \\
\hline $\mathrm{Na}_{2}\left[\mathrm{Co}(\text { asp })_{2}\right]$ & $14.0 \pm 0.3$ & $6.0 \pm 0.5$ & $6.0 \pm 1.1$ & $6.0 \pm 0.2$ & $10.0 \pm 0.2$ & $18.0 \pm 0.1$ & $17.0 \pm 0.0$ \\
\hline $\mathrm{Na}_{2}\left[\mathrm{Mn}(\mathrm{asp})_{2}\right]$ & $6.0 \pm 0.7$ & $6.0 \pm 0.9$ & $13.0 \pm 0.0$ & $6.0 \pm 0.2$ & $6.0 \pm 0.7$ & $13.0 \pm 0.3$ & $6.0 \pm 0.1$ \\
\hline C & $20.0 \pm 0.4$ & $6.0 \pm 0.0$ & $15.0 \pm 0.6$ & $20.0 \pm 0.2$ & $6.0 \pm 0.9$ & $6.0 \pm 0.7$ & $19.0 \pm 0.1$ \\
\hline
\end{tabular}

C: Acriflavine.

+: Gram-positive bacteria.

-: Gram-negative bacteria.

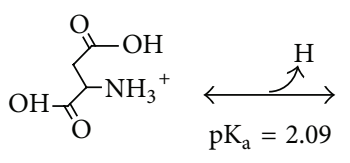

(a)

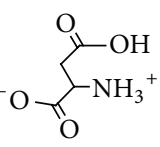

(b)

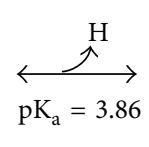<smiles>COC(=O)C(=O)[O-]</smiles>

(c)

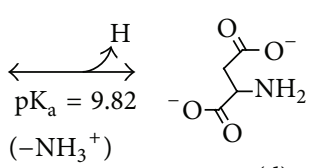

(d)

FIGURE 8: Coordination behaviour of aspartic acid: a function of the $\mathrm{pH}$ of the reaction. (a) In strong acid (below $\mathrm{pH} 1$ ); net charge $=+1$. (b) Around $\mathrm{pH} 3$; net charge $=0$. (c) Around $\mathrm{pH} 6-8$; net charge $=-1$. (d) In strong alkali (above pH 11) net charge $=-2$.

the nitrogen atom may be used for coordination. Previous studies have shown this to be due to the strong electron-donor (basic) character of the $\mathrm{N}$ atom of the $\mathrm{NH}_{2}$ group and stability of the chelate ring [42-44]. This in addition is supported by the flexibility of the amino acid ligand. It was also observed that the geometry of the complexes was not determined only by the ligand, but the metal ions as well $[13,16-20]$. This is because the complexes assume geometries better suited for the metal ions, resulting in the variations observed for some of the complexes.

3.5. Antimicrobial. The results obtained indicated that the compounds exhibited a broad spectrum of activity against the tested bacteria and fungi strains and in some cases better activity compared to the standard. Some of the complexes exhibited better activity compared to the ligand, consequently lending support to the chelation theory $[2,26,45-50]$. In line with previous reports the compounds exhibited better activity generally against Gram-positive bacteria. This has been attributed to the increased hydrophobic character of these molecules in crossing the cell membrane of the microorganism. As a consequence, the utilization ratio of the compounds is enhanced $[1-6,26,45]$.

Generally the $\mathrm{ML}_{2}$ complexes exhibited better activity compared to the $\mathrm{Na}_{2}\left[\mathrm{ML}_{2}\right]$ complexes with the exception of the copper and manganese complexes. The better activity of the $\mathrm{ML}_{2}$ complexes compared to the $\mathrm{Na}_{2}\left[\mathrm{ML}_{2}\right]$ complexes in some cases may be ascribed to the enhanced lipophilicity of the former as a result of its nonionic nature as against the positively charged latter $[2,26,45-50]$. The $\mathrm{Na}_{2}\left[\mathrm{Cd}(\mathrm{asp})_{2}\right]$ complex gave good activity against $C$. albicans, while $\mathrm{Cd}(\mathrm{asp})_{2}$ exhibited marginal activity against the fungi (Table 4). This indicates the activity of the metal ion as an antifungal agent. It also points to the fact that enhanced lipophilicity as a result of the tridentate nature of the ligand may increase the activity of the complex $[2,26,45-50]$. It is suggested that the size and number of chelate rings may play a role in the enhanced activity of these compounds in this case. The $\mathrm{Cu}(\mathrm{asp})_{2}$ complex exhibited the best activity, contrary to that obtained in previous report for similar coordination compounds $[24,26,51]$. The $\mathrm{Na}_{2}\left[\mathrm{Cu}(\text { asp })_{2}\right]$ exhibited good activity against $S$. aureus, indicating the effect of the metal ion as an antimicrobial agent [51]. The activity of some of the complexes against B. subtilis, MRSA, Ps. Aeruginosa, and $C$. Albicans (Table 4) was significantly higher than the standard drug $(p<0.05)$. This indicates their potentials as antimicrobial agents against these microbes.

\section{Conclusion}

In this study coordination compounds of aspartic acid were synthesized in both acidic and basic media. It was concluded that the geometry assumed by the synthesized compounds was a function of available donor atoms of the ligand and this is dependent on the relevant $\mathrm{pH}$ in which the reaction was carried out. The complexes exhibited a broad 
spectrum of activity. In some cases complexes synthesized in basic medium exhibited better activity compared to their counterpart complexes obtained in acidic medium. This was attributed to their enhanced lipophilicity as a result of the increased number of chelate rings.

\section{Competing Interests}

The authors declare that they have no competing interests.

\section{Acknowledgments}

T. O. Aiyelabola is grateful to NWU for a postdoctoral fellowship and the Sasol Inzalo, NRF fellowship.

\section{References}

[1] D. Kumar, A. Kumar, and D. Dass, "Syntheses and characterization of the coordination compounds of N-(2-hydroxymethylphenyl)-C-(3'-carboxy-2'-hydroxyphenyl)thiazolidin-4-one," International Journal of Inorganic Chemistry, vol. 2013, Article ID 524179, 6 pages, 2013.

[2] Z. H. Chohan, M. Arif, M. A. Akhtar, and C. T. Supurean, "Metal-based antibacterial and antifungal agents: synthesis, characterization, and in vitro biological evaluation of $\mathrm{Co}(\mathrm{II})$, $\mathrm{Cu}(\mathrm{II}), \mathrm{Ni}(\mathrm{II})$, and $\mathrm{Zn}$ (II) complexes with amino acid-derived compounds," Bioinorganic Chemistry and Application, vol. 2009, Article ID 83131, 13 pages, 2006.

[3] I. Bertini, H. B. Gray, E. I. Stiefel, and J. S. Valentine, Biological Inorganic Chemistry: Structure and Reactivity, University Science Books, Sausalito, Calif, USA, 1st edition, 2007.

[4] N. P. Farrell, "Metal-based chemotherapeutic drugs", in The Uses of Inorganic Chemistry in Medicine, The Royal Society of Chemistry, Cambridge, UK, 1999.

[5] A. F. Husseiny, E. S. Aazam, and J. Al Shebary, "Synthesis, characterization and antibacterial activity of schiff-base ligand incorporating coumarin moiety and it metal complexes," Inorganic Chemistry, vol. 3, pp. 64-68, 2008.

[6] N. P. Farrell, "Catalysis by metal complexes," in Transition Metal Complexes as Drugs and Chemotherapeutic Agents, B. R. James and R. Ugo, Eds., vol. 11, p. 304, Reidel-Kluwer Academic Press, Dordrecht, Netherlands, 1989.

[7] R. Bregier-Jarzebowska, A. Gasowska, and L. Lomozik, "Complexes of $\mathrm{Cu}(\mathrm{II})$ ions and noncovalent interactions in systems with L-aspartic acid and cytidine-5'-monophosphate," Bioinorganic Chemistry and Applications, vol. 2008, Article ID 253971, 10 pages, 2008

[8] A. L. Lehninger, D. L. Nelson, and M. M. Cox, "Amino acids building blocks of proteins," in Principles of Biochemistry, pp. 71-95, W. H. Freeman/CBS, New York, NY, USA, 3rd edition, 2005.

[9] L. Kryger and S. E. Rasmussen, "Walden inversion. III. The crystal structure and absolute configuration of $\mathrm{Zn}(\mathrm{II})(+)-$ aspartate trihydrate," ActaChimie Scandinavian, vol. 27, pp. 2674-2676, 1973.

[10] L. Antolini, L. Menabue, G. C. Pellacani, and G. Marcotrigiano, "Structural, spectroscopic, and magnetic properties of diaqua(L-aspartato)nickel(II) hydrate," Journal of the Chemical Society, Dalton Transactions, no. 12, pp. 2541-2543, 1982.
[11] T. Yasui and T. Ama, "Metal complexes of amino acids. VIII. Carbon-13 nuclear magnetic resonances of cobalt(III) complexes containing L-aspartic and L-glutamic acids," Bulletin of the Chemical Society of Japan, vol. 48, no. 11, pp. 3171-3174, 1975.

[12] K. Bukietyńska, H. Podsiadły, and Z. Karwecka, "Complexes of vanadium(III) with L-alanine and L-aspartic acid," Journal of Inorganic Biochemistry, vol. 94, no. 4, pp. 317-325, 2003.

[13] K. Nomiya and H. Yokoyama, "Syntheses, crystal structures and antimicrobial activities of polymeric silver(I) complexes with three amino-acids [aspartic acid $\left(\mathrm{H}_{2} \mathrm{asp}\right)$, glycine (Hgly) and asparagine (Hasn)]," Journal of the Chemical Society, Dalton Transactions, no. 12, pp. 2483-2490, 2002.

[14] A. V. Legler, A. S. Kazachenko, V. I. Kazbanov, O. V. Per'yanova, and O. F. Veselova, "Synthesis and antimicrobial activity of silver complexes with arginine and glutamic acid," Pharmaceutical Chemistry Journal, vol. 35, no. 9, pp. 501-503, 2001.

[15] T. Komiyama, S. Igarashi, and Y. Yukawa, "Synthesis of polynuclear complexes with an amino acid or a peptide as a bridging ligand," Current Chemical Biology, vol. 2, no. 2, pp. 122-139, 2008.

[16] R. F. See, R. A. Kruse, and W. M. Strub, "Metal-ligand bond distances in first-row transition metal coordination compounds: coordination number, oxidation state, and specific ligand effects," Inorganic Chemistry, vol. 37, no. 20, pp. 5369-5375, 1998.

[17] D. A. Buckingham, "Structure and stereochemistry of coordination compounds," in Inorganic Biochemistry, G. Eichhorn, Ed., pp. 3-61, Elsevier, London, UK, 1973.

[18] J. J. R. F. da Silva and R. J. P. Williams, The Biological Chemistry of the Elements, Oxoford University Press, Oxford, UK, 2nd edition, 1984.

[19] R. H. Holin, G. W. Everett Jr., and A. Chakravorty, "Metal complexes of schiff bases and $\beta$-ketoamine," in Progress in Inorganic Chemistry, F. A. Cotton, Ed., vol. 7, pp. 83-214, WileyInterscience, New York, NY, USA, 3rd edition, 2009.

[20] D. P. Mellor, "Historical background and fundamental concept," in Chelating Agents and Metal Chelate, F. P. Dwyer and D. Mellor, Eds., pp. 1-48, Academic Press, New York, NY, USA, 1964.

[21] K. Nomiya, S. Takahashi, R. Noguchi, S. Nemoto, T. Takayama, and M. Oda, "Synthesis and characterization of water-soluble silver(I) complexes with L-histidine $\left(\mathrm{H}_{2}\right.$ his $)$ and $(S)-(-)$ 2-pyrrolidone-5-carboxylic acid $\left(\mathrm{H}_{2}\right.$ pyrrld) showing a wide spectrum of effective antibacterial and antifungal activities. Crystal structures of chiral helical polymers $[\mathrm{Ag}(\mathrm{Hhis})] n$ and $\left\{[\mathrm{Ag}(\mathrm{Hpyrrld})]_{2}\right\} n$ in the solid state," Inorganic Chemistry, vol. 39, no. 15, pp. 3301-3311, 2000.

[22] Y. Hui, H. Qizhuang, Z. Meifeng, X. Yanming, and S. Jingyi, "Synthesis, characterization and biological activity of rare earth complexes with L-aspartic acid and o-phenanthroline," Journal of the Chinese Rare Earth Society, vol. 2, pp. 3-4, 2007.

[23] P. R. Murray, E. J. Baroon, M. A. Pfaller, F. C. Tenover, and R. H. Yolke, Manual of Clinical Microbiology, American Society for Microbiology, Washington, DC, USA, 6th edition, 1995.

[24] T. O. Aiyelabola, O. Isaac, and A. Olugbenga, "Structural and antimicrobial studies of coordination compounds of phenylalanine and glycine," International Journal of Chemistry, vol. 4, no. 2, article 49, 2012.

[25] S. Yamada, J. Hidaka, and B. E. Douglas, "Characterization of the three isomers of sodium bis(L-aspartato)cobaltate(III)," Inorganic Chemistry, vol. 10, no. 10, pp. 2187-2190, 1971.

[26] T. O. Aiyelabola, I. A. Ojo, A. C. Adebajo et al., "Synthesis, characterization and antimicrobial activities of some metal(II) 
amino acids' complexes," Advances in Biological Chemistry, vol. 2, pp. 268-273, 2012.

[27] D. Pavia, G. Lampman, and G. Kriz, "Infrared spectroscopy," in Introduction to Spectroscopy, A Guide for Students of Organic Chemistry, pp. 22-368, Brooks and Cole, New York, NY, USA, 3rd edition, 2001.

[28] K. Nakamoto, "Complexes of amino acids," in Infrared and Raman Spectra of Inorganic and Coordination Compounds, K. Nakamoto, Ed., pp. 66-74, Wiley Interscience, New York, NY, USA, 2009.

[29] W. Kemp, "Infrared spectroscopy," in Organic Spectroscopy, pp. 22-38, Macmillan, Hong Kong, 1991.

[30] L. J. Bellamy, The Infrared Spectra of Complex Molecules, Chapman \& Hall, London, UK, 1975.

[31] A. A. Osunlaja, N. P. Ndahil, and J. A. Ameh, "Synthesis, physico-chemical and antimicrobial properties of $\mathrm{Co}(\mathrm{II}), \mathrm{Ni}(\mathrm{II})$ and $\mathrm{Cu}$ (II) mixed-ligand complexes of dimethylglyoxime-part I," African Journal of Biotechnology, vol. 8, no. 1, pp. 4-11, 2009.

[32] N. N. Greenwood and A. Earnshaw, "Coordination compounds," in Chemistry of the Elements, pp. 1060-1090, Butterworth-Heinemann, Oxford, UK, 2nd edition, 1997.

[33] A. A. Osowole, G. A. Kolawole, and O. E. Fagade, "Synthesis, characterization and biological studies on unsymmetrical Schiff-base complexes of nickel(II), copper(II) and zinc(II) and adducts with 2,2'-dipyridine and 1,10-phenanthroline," Journal of Coordination Chemistry, vol. 61, no. 7, pp. 1046-1055, 2008.

[34] A. B. P. Lever, "Crystal field spectra," in Inorganic Electronic Spectroscopy, pp. 481-579, Elsevier, London, UK, 1986.

[35] F. A. Cotton, G. Wilkinson, and C. A. Murillo, "Chemistry of the transition elements," in Advanced Inorganic Chemistry, pp. 420-1375, Wiley Interscience, New York, NY, USA, 6th edition, 1999.

[36] W. E. Estes, D. P. Gavel, W. E. Hatfield, and D. J. Hodgson, "Magnetic and structural characterization of dibromo- and dichlorobis(thiazole)copper(II)," Inorganic Chemistry, vol. 17, no. 6, pp. 1415-1421, 1978.

[37] C. J. Ballhausen, In An Introduction to Ligand Field Theory, McGraw Hill, New York, NY, USA, 1962.

[38] N. Raman, K. Pothiraj, and T. Baskaran, "Synthesis, characterization, and DNA damaging of bivalent metal complexes incorporating tetradentate dinitrogen-dioxygen ligand as potential biocidal agents," Journal of Coordination Chemistry, vol. 64, no. 24, pp. 4286-4300, 2011.

[39] J. R. Anacona, T. Martell, and I. Sanchez, "Metal complexes of a new ligand derived from 2,3-quinoxalinedithiol and 2,6bis(bromomethyl)pyridine," Journal of the Chilean Chemical Society, vol. 50, no. 1, pp. 375-378, 2005.

[40] G. L. Miessler and D. A. Tarr, Coordination Compounds, Pearson Prentice Hall, New York, NY, USA, 1999.

[41] A. A. Osowole, "Synthesis, characterization, and magnetic and thermal studies on some metal(II) thiophenyl schiff base complexes," International Journal of Inorganic Chemistry, vol. 2011, Article ID 650186, 7 pages, 2011.

[42] H. C. Freeman, "Metal complexes of amino acid and peptides," in Inorganic Biochemistry, G. Eichhorn, Ed., pp. 121-150, Elsevier, London, UK, 1973.

[43] R. Murray, D. Granner, and V. Rodwell, "Biochemistry," in Harper's Illustrated. Lange Medical Books, P. J. Kennelly and V. W. Rodwell, Eds., vol. 77, McGraw-Hill, London, UK, 2006.

[44] E. Fakas and I. Solvago, "Metal complexes of amino acids and peptides," in Amino Acids, Peptides and Proteins, J. S. Davies,
Ed., vol. 35, pp. 353-434, Royal Society of Chemistry, London, UK, 2006.

[45] Z. H. Chohan, S. H. Sumrra, M. H. Youssoufi, and T. B. Hadda, "Synthesis and in vitro cytostatic activity of new $\beta$-d-arabino furan $\left[1^{\prime}, 2^{\prime}: 4,5\right]$ oxazolo- and arabino-pyrimidinone derivatives," European Journal of Medicinal Chemistry, vol. 45, no. 2, pp. 831839, 2006.

[46] P. K. Panchal, H. M. Parekh, P. B. Pansuriya, and M. N. Patel, "Bactericidal activity of different oxovanadium(IV) complexes with Schiff bases and application of chelation theory," Journal of Enzyme Inhibition and Medicinal Chemistry, vol. 21, no. 2, pp. 203-209, 2006.

[47] N. Raman, V. Muthuraj, S. Ravichandran, and A. Kulandaisamy, "Synthesis, characterisation and electrochemical behaviour of $\mathrm{Cu}(\mathrm{II}), \mathrm{Co}(\mathrm{II}), \mathrm{Ni}(\mathrm{II})$ and $\mathrm{Zn}(\mathrm{II})$ complexes derived from acetylacetone and $p$-anisidine and their antimicrobial activity," Journal of Chemical Sciences, vol. 115, no. 3, pp. 161-167, 2003.

[48] N. Raman and A. Kulandaisany, "Synthesis, spectral, redox and antimicrobial activities of Schiff base complexes derived from 1-phenyl-2,3-dimethyl-4-aminopyrazol-5-one and acetoacetanilide," Transition Metal Chemistry, vol. 26, no. 1, pp. 131135, 2001.

[49] M. Shakir, S. Hanif, M. A. Sherwani, O. Mohammad, and S. I. Al-Resayes, "Pharmacologically significant complexes of $\mathrm{Mn}(\mathrm{II}), \mathrm{Co}(\mathrm{II}), \mathrm{Ni}(\mathrm{II}), \mathrm{Cu}(\mathrm{II})$ and $\mathrm{Zn}(\mathrm{II})$ of novel Schiff base ligand, (E)-N-(furan-2-yl methylene) quinolin-8-amine: synthesis, spectral, XRD, SEM, antimicrobial, antioxidant and in vitro cytotoxic studies," Journal of Molecular Structure, vol. 1092, Article ID 21396, pp. 143-159, 2015.

[50] C. Jayabalaknshnan, R. Kervembu, and K. Natarajan, "Catalytic and antimicrobial activities of new ruthenium(II) unsymmetrical Schiff base complexes," Transition Metal Chemistry, vol. 27, no. 7, pp. 790-794, 2002.

[51] G. Grass, G. Rensing, and M. Solioc, "Metallic copper as an antimicrobial surface," Applied and Environmental Microbiology, vol. 77, no. 5, pp. 1541-1547, 2011. 

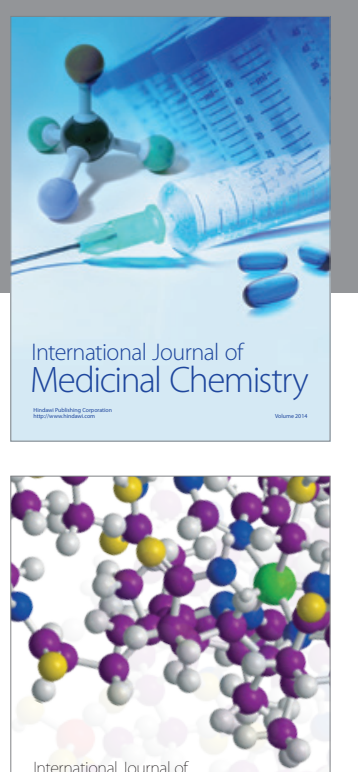

Carbohydrate Chemistry

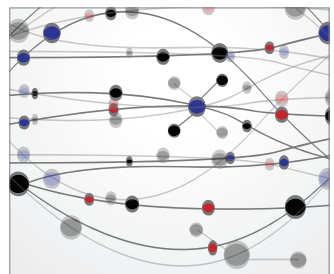

The Scientific World Journal
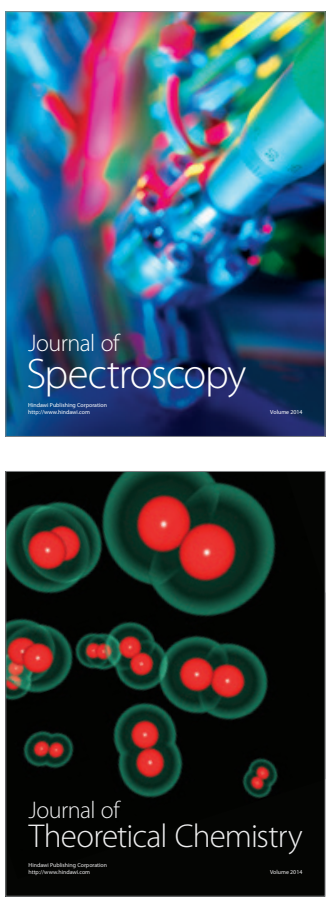
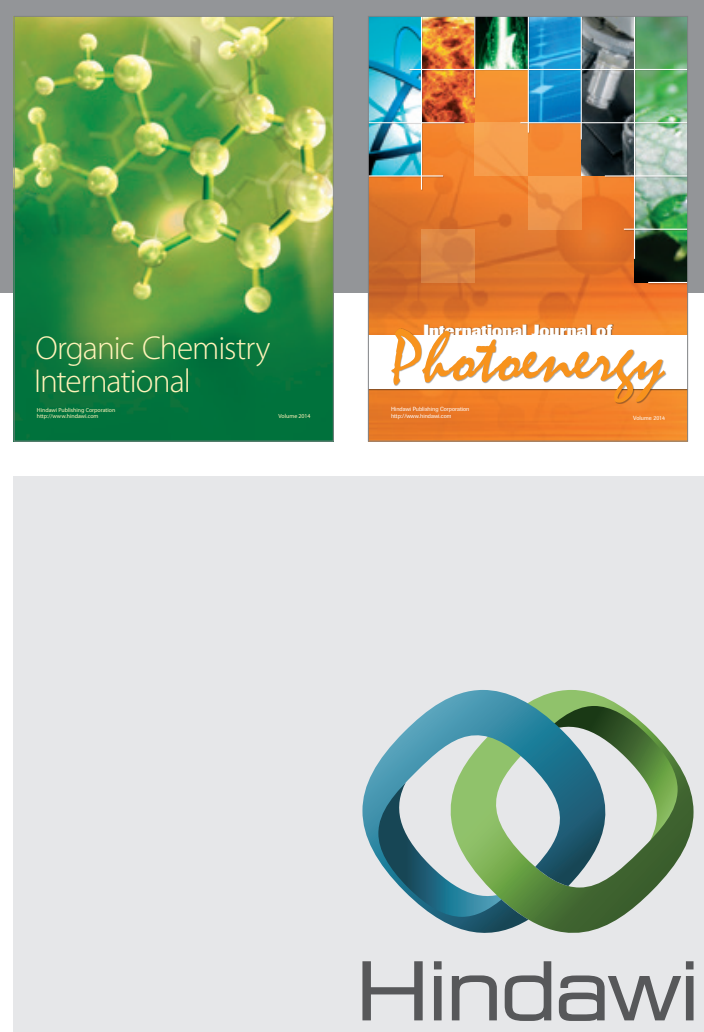

Submit your manuscripts at

http://www.hindawi.com

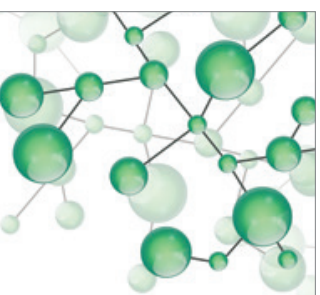

International Journal of

Inorganic Chemistry

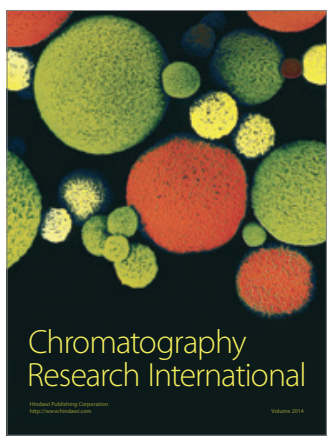

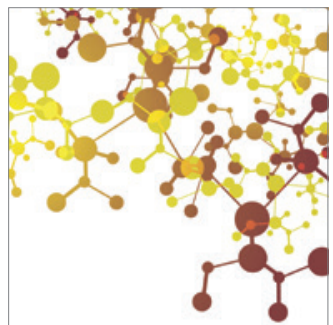

Applied Chemistry
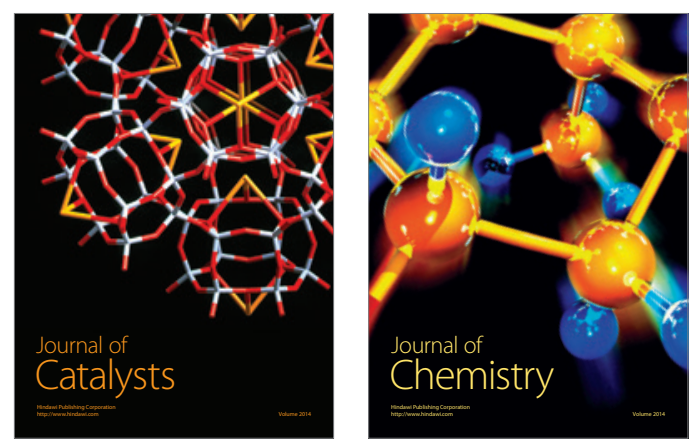
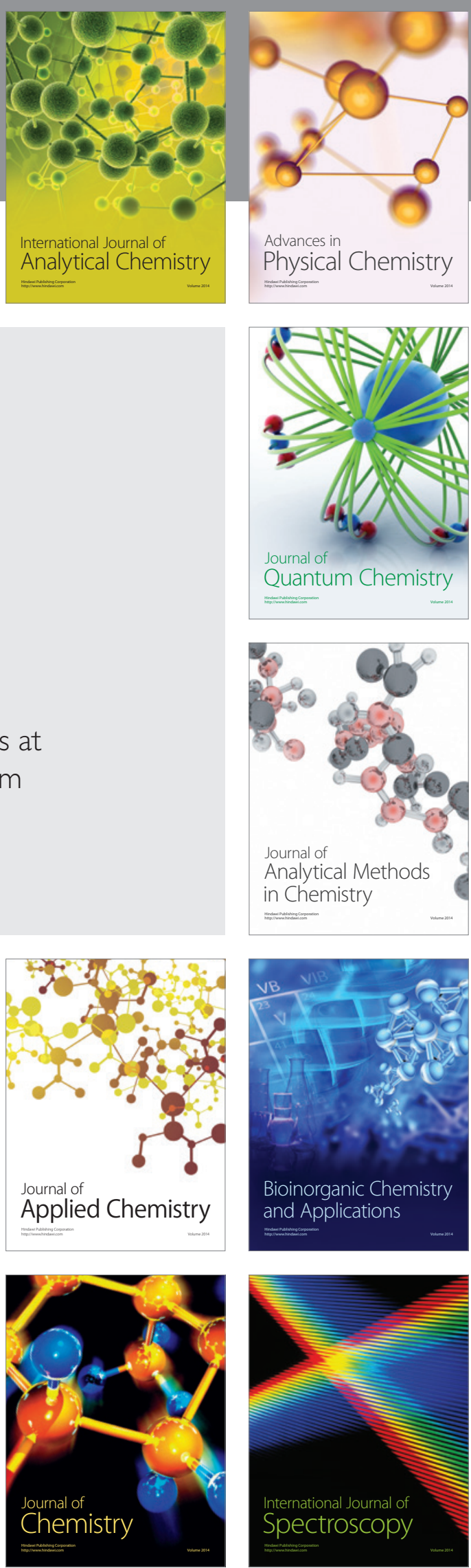